LWSA

Local Wisdom, Social, and Arts

PAPER - OPEN ACCESS

Mobilitas Sosial Penduduk Berbasis Industri Pariwisata Dalam Meningkatkan Status Sosial Ekonomi Masyarakat di Kota Gunung Sitoli, Nias Propinsi Sumatera Utara
Author
: Sismudjito Sismudjito
DOI
: 10.32734/lwsa.v1i1.164
Electronic ISSN
: 2654-7058
Print ISSN
: 2654-7066

Volume 1 Issue 1 - 2018 TALENTA Conference Series: Local Wisdom, Social and Arts

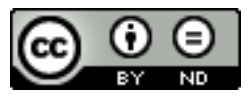

This work is licensed under a Creative Commons Attribution-NoDerivatives 4.0 International License.

Published under licence by TALENTA Publisher, Universitas Sumatera Utara
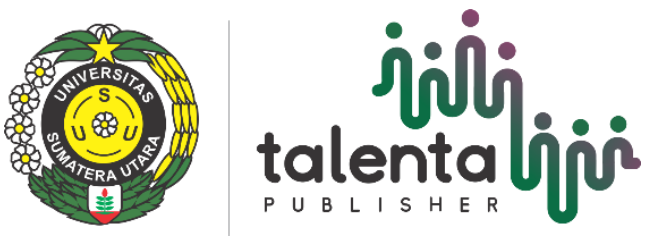


\title{
Mobilitas Sosial Penduduk Berbasis Industri Pariwisata Dalam Meningkatkan Status Sosial Ekonomi Masyarakat di Kota Gunung Sitoli, Nias Propinsi Sumatera Utara
}

\author{
Sismudjito $^{\text {a }}$, Syafruddin Pohan ${ }^{\mathrm{a}}$, Kariono ${ }^{\mathrm{a}}$ \\ ${ }^{a}$ Staff Pengajar FISIP USU,Medan, Indonesia
}

\begin{abstract}
Pertumbuhan Kunjungan wisatawan ke Kabupaten Nias beberapa tahun belakangan menggambarkan peningkatan aktifitas sosialekonomi masyarakat Nias di bidang pariwisata. Peningkatan aktifitas sosial-ekonomi ini menjadi salah satu faktor pemicu mobilitas sosial penduduk dalam meningkatkan kesejahteraan masyarakat Nias. Penelitian ini bertujuan untuk menemukan jawaban apakah mobilitas penduduk Nias melalui aktifitas yang berbasis industri pariwisata dapat meningkatkan status sosialekonomi masyarakatnya; serta bagaimana mobilitas sosial penduduk Nias dalam meningkatkan status sosial-ekonomi yang berbasis pariwisata.

Landasan teori dalam penelitian ini adalah mobilitas sosial yang diimplementasikan oleh sebagian anggota masyarakat yang telah memiliki tingkat daya terima (aksesibilitas) yang tinggi. Bekerjanya mobilitas sosial dan aksesibilitas tersebut dapat meningkatkan status sosial ekonomi para anggota masyarakat melalui aktifitas sosial. Penelitian ini menggunakan metode penelitian gabungan yang merupakan kombinasi metode penelitian kuantitatif dan kualitatif. Penarikan sampel dilakukan secara acak (sampling of random) dengan analisis data menggunakan teknik distribusi frekuensi.

Hasil penelitian menjelaskan mobilitas sosial penduduk dengan beberapa jenis pergerakan sosial, diantara pergerakan tersebut yaitu mobilitas sosial horizontal, mobilitas sosial vertical naik, mobilitas vertikal turun, mobilitas sosial antar generasi, dan mobilitas sosial intra generasi yang berdampak pada tingkat aksesibilitas para anggota masyarakatnya.
\end{abstract}

Kata kunci: Mobilitas sosial; pariwisata; status sosial-ekonomi

\section{Pendahuluan}

Pertumbuhan industri pariwisata di Indonesia tahun 2014 mencapai 9,39 persen lebih tinggi dari tahun sebelumnya. Angka itu di atas pertumbuhan ekonomi nasional yang mencapai 5,7 persen. Sektor pariwisata benar-benar akan menjadi andalan pengungkit ekonomi yang handal. Pariwisata juga telah memberikan devisa yang cukup besar bagi negara. Sejak tahun 1978, pemerintah terus berusaha untuk mengembangkan kepariwisataan. Hal ini dituangkan dalam TAP MPRNo. IV/MPR/1978, yaitu bahwa pariwisata perlu ditingkatkan dan diperluas untuk meningkatkan penerimaan devisa, memperluas lapangan kerja dan memperkenalkan kebudayaan. Pembinaan serta pengembangan pariwisata dilakukan dengan tetap memperhatikan terpeliharanya kebudayaan dan kepribadian nasional. Untuk itu perlu diambil langkah-langkah yang lebih terarah berdasarkan kebijaksanaan yang terpadu, antara lain bidang promosi, penyediaan fasilitas serta mutu dan kelancaran pelayanan. 
Perekonomian pulau Nias pada umumnya bertumpu sektor pertanian, nelayan, sektor-sektor lainnya termasuk pariwisata. Fakta ini terlihat dalam data BPS tahun 2011, sektor pertanian mendominasi, yang menyumbang hampir $60 \%$ pendapatan Daerah Asli Daerah (PAD). Seiring dengan berjalannya waktu, sektor-sektor lain mulai menunjukkan keunggulannya dalam menyumbang pendapatan daerah Nias. Salah satunya adalah sektor pariwisata.

Pulau Nias adalah sebuah wilayah di Provinsi Sumatera Utara yang dikenal karena potensi wisatanya.Potensi wisata pulau Nias telah disadari oleh masyarakat Nias sebagai sebuah peluang untuk meningkatkan ekonomi mereka.Status sosial ekonomi masyarakat Nias tergolong cukup rendah.Fakta itu, dibuktikan dari data BPS tentang pendapatan perkapita masyarakat Nias. Pada tahun 2010, pendapatan perkapita masyarakat Nias adalah Rp. 3.887.995,- pertahun (BPS, 2011). Angka tersebut merupakan pendapatan perkapita terendah di seluruh kota di Sumatera Utara. Hal itu, menunjukkan bahwa masyarakat Nias belum bisa memanfaatkan secara optimal seluruh potensi alam yang mereka miliki. Oleh karenanya, pemerintah setempat memaksimalkan sektor pariwisata di Nias untuk meningkatkan perekonomian masyarakat.

Sebagaimana Kepulauan Nias yang memiliki potensi pariwisata yang sangat besar dan beraneka ragam, Nias juga memiliki ragam potensi wisata antaralain : wisata alam, wisata bahari, dan wisata budaya/peninggalan sejarah merupakan objek petualangan. Terdapat beberapa objek wisata spetakuler, diantaranya rumah adat,batu megalith dan budaya yang unik. Kawasan wisata yang saat ini sedang dikembangkan oleh Pemerintah Kabupaten Nias yaitu Kawasan Wisata SOZIONA (Somi, Bozihona, Onolimbu, dan Nalawo) merupakan kawasan wisata bahari dengan pantai pasir putih yang indah, biota bawah laut yang sangat baik untuk diving, wisata memancing, serta panorama 4 buah pulau yang masih sangat alami. (Data BPS Nias, 2012).

Kebanyakan penduduk Nias menjadikan pariwisata sebagai mata pencaharian meski sebagian besar diantaranya juga tetap bertani ataupun berdagang secara partikelir.Jumlah kunjungan wisatawan ke Nias sendiri cenderung meningkat dalam beberapa tahun belakangan. Peningkatan jumlah kunjungan wisatawan ke Nias dapat dilihat pada tabel berikut:

Tabel 1.Perkembangan Jumlah Wisatawan Yang Berkunjung Di Kabupaten Nias Tahun2009 - 2012

\begin{tabular}{ccccc}
\hline Tahun & & Wisatawan Asing & Wisatawan Domestik & Jumlah \\
\hline 2009 & 126 & 6070 & 6196 \\
2010 & 248 & 6438 & 6686 \\
2011 & 273 & 7082 & 7355 \\
2012 & 310 & 7791 & 8091 \\
\hline
\end{tabular}

Sumber: BPS Kabupaten Nias Tahun 2013

Meningkatnya jumlah kunjungan wisatawan asing dan domestik ke Kabupaten Nias dari tahun ke tahun turut menggambarkan peningkatan aktifitas ekonomi masyarakat Nias dibidang pariwisata.Kondisi tersebut tidak menutup kemungkinan partisipasi yang lebih luas dari masyarakat luar maupun masyarakat Nias sendiri untuk terjun kedalam industri pariwisata di Nias. Potensi pariwisata Nias yang besar serta kebutuhan pemenuhan sarana dan prasarana pariwisata Nias akan memicu pertumbuhan aktifitas ekonomi masyarakat Nias. Kondisi ini, pada gilirannya juga akan memicu mobilitas sosial masyarakat Nias.

Pariwisata di Nias merupakan manifestasi dari pemanfaatan potensi alam selain sektor pertanian. Sumber daya alam yang berlimpah membutuhkan kualitas manusia yang tinggi untuk mengelola sumber daya alam tersebut menjadi sumber peningkatan kesejahteraan. Adanya agent of change (agen perubahan) yang membawa masyarakat Nias untuk memajukan pariwisata di sana merupakan bentuk dari mobilitas sosial masyarakat.

Masyarakat senantiasa berubah seiring berjalannya waktu dan informasi yang diperoleh. Dengan perkembangan sektor pariwisata di Nias, masyarakat dipaksa untuk memiliki sifat inovatif dan daya terima terhadap dunia luar untuk dapat terus meningkatkan pemanfaatan potensi pariwisata di daerah mereka. Hal tersebut merupakan ciri dari manusia modern seperti yang diusung oleh Alex Inkeles (dalam Weiner, 1981). 
Berkembangnya sektor pariwisata di Nias beriringan dengan meningkatnya mobilitas sosial pada masyarakat setempat. Usaha-usaha turunan yang muncul untuk mendukung pariwisata semakin bertambah dan berkembang. Hal tersebut menunjukkan bahwa masyarakat Nias memiliki daya terima terhadap dunia luar yang tinggi. Lebih jauh lagi, hal tersebut tentunya dapat meningkatkan status sosial ekonomi masyarakat.

Dewasa ini, masyarakat semakin banyak melakukan mobilitas sosial yang lebih baik dengan anggapan agar kehidupannya bisa lebih sejahtera.Masyarakat yang sudah memiliki mobilitas yang tinggi bahkan menginginkan pencapaian yang lebih tinggi lagi.Sedangkan bagi masyarakat yang memiliki mobilitas yang rendah berusaha untuk memiliki mobilitas sosial yang lebih tinggi dari yang telah diraihnya saat ini.

Melakukan pergeseran dalam gerak sosial menjadi hal sangat penting bagi suatu kelompok sosial.Selain untuk meningkatkan citra suatu kelompok, juga digunakan untuk memperbaiki tingkat perekonomian dalam kelompok.Mobilitas yang terjadi pada masa lalu merupakan mobilitas sosial yang masih berjalan sesuai dengan keadaan hidup.Berbeda dengan yang sekarang, mobilitas sosial seringkali mengalami rekayasa dari anggota kelompoknya.Penyebab utama dilakukannya rekayasa tersebut karena sulitnya pencapaian mobilitas sosial pada era sekarang ini.

Mobilitas sosial mempunyai konsekuensi terhadap kehidupan sehari-hari sama seperti stratifikasi sosial dan diferensiasi sosial, karena pada dasarnya mobilitas sosial memiliki hubungan erat dengan struktur sosial (stratifikasi dan diferensiasi). Mobilitas sosial merupakan proses perpindahan seseorang atau sekelompok orang dari kelas atau kelompok sosial yang satu menuju kelas atau kelompok sosial lainnya. Apabila seseorang berpindah dari satu status sosial menuju status sosial lain, tentu dia menghadapi beberapa kemungkinan. Kemungkinan-kemungkinan itu antara lain penyesuaian diri, terlibat konflik dengan kelas atau kelompok sosial yang baru dimasukinya dan beberapa hal lain yang menyenangkan atau justru mengecewakan.

Mobilitas sosial memiliki beberapa jenis pergerakan sosial, diantara pergerakan tersebut yaitu mobilitas sosial horizontal, mobilitas sosial vertikal naik, mobilitas vertikal turun, mobilitas sosial antargenerasi, dan mobilitas sosial intragenerasi.Dari beberapa bentuk mobilitas sosial, memiliki ciri-ciri yang berbeda satu dengan yang lainnya.

Faktor terjadinya mobilitas sosial dibagi menjadi dua macam. Faktor tersebut ialah faktor pendorong mobilitas sosial dan faktor penghambat mobilitas sosial. Faktor pendorong merupakan faktor yang mendukung atau memfasilitasi hingga proses dari mobilitas sosial berjalan. Sedangkan faktor penghambat merupakan faktor yang menghambat atau faktor yang kontra terhadap berjalannya proses mobilitas sosial. Keduanya memiliki faktor yang bertolak belakang.

Selain faktor mobilitas sosial, terdapat juga dua dampak yang ditimbulkan dari mobilitas sosial.Dampak tersebut ialah dampak positif juga dampak negatif.Dampak positif merupakan akibat dari terjadinya mobilitas sosial yang menguntungkan pihak yang melakukan mobilitas sosial, sedangkan dampak negatif merupakan akibat dari terjadinya mobilitas sosial yang justru merugikan orang yang melakukan mobilitas sosial.

Struktur masyarakat yang terbuka menimbulkan kesempatan terjadinya mobilitas secara luas. Setiap orang bisa mencapai status sosial yang diinginkannya asal berusaha keras, dapat dilihat dalam masyarakat demokratis yang memberikan kesempatan sama kepada semua warganya. Tidak ada halangan bagi siapapun untuk mencapai kedudukan, pekerjaan, atau penghasilan yang lebih tinggi.

Serangkaian proposisi yang telah diuraikan dalam latar belakang masalah, maka dapat diformulasikan beberapa bentuk pokok masalah sebagai berikut :

1. Apakah mobilitas penduduk Kota Gunung Sitoli, Nias melalui aktifitas yang berbasis industri pariwisata dapat meningkatkan kesejahteraan masyarakatnya?

2. Bagaimana mobilitas sosial penduduk Kota Gunung Sitoli Nias dalam meningkatkan kesejahteraan masyarakat berbasis pariwisata?

Bermula dari dua pokok masalah yang telah diformulasikan di atas, maka penelitian ini bertujuan untuk melihat apakah mobilitas penduduk Nias khususnya di Kota Gunung Sitoli dalam meningkatkan kesejahteraan masyarakat berbasis sektor pariwisata dan bagaimana keberadaan sektor pariwisata mempengaruhi mobilitas penduduk di kota Gunung Sitoli sehingga mampu menumbuhkan kesejahteraan di pulau Nias, Khususnya di kota Gunung Sitoli. 


\section{Landasan teori}

Deskripsi singkat tentang sektor pariwisata, Menurut Murphy ( Luthfi, 2013) pariwisata adalah keseluruhan dari elemen-elemen terkait (wisatawan, daerah tujuan wisata, perjalanan, industri, dan lain-lain).

\section{Mobilitas Sosial}

Mobilitas sosial (gerak sosial) atau social mobility adalah suatu gerak dalam struktur sosial (social structure) yaitu pola-pola tertentu yang mengatur organisasi suatu kelompok sosial. Struktur sosial mencakup sifat-sifat hubungan antara individu dalam kelompok dan hubungan antara individu dengan kelompoknya (Soekanto, 2012:219). Semua lapisan masyarakat akan mengalami proses mobilitas sosial dengan cara yang beragam, guna mengawasi perilaku dari invidu itu sendiri. Mobilitas sosial tersebut bergerak ketika seorang individu berpindah dari satu posisi tingkatan ke tingkatan yang lain, baik setara maupun berbeda.

Kalau kemungkinan mobilitas sosial tidak ada, kelompok bawah berusaha terus untuk meningkatkan statusnya sebagai kelompok (Sarwono,2005:92). Peningkatan status kelompok yang bisa dilakukan dengan berbagai cara yaitu dengan meningkatkan status kelompok keatas, jika hal itu tidak bisa dilakukan maka dengan cara meningkatkan kualitas kelompok tersebut baik dalam segi kesenian dan budaya. Hal tersebut dilakukan agar citra dari kelompok tersebut tidak dipandang jelek oleh kelompok yang lainnya. Walaupun tidak berkembang dalam hal pendidikan, namun setidaknya dalam bidang yang lain masih memiliki keunggulan dibandingkan dengan kelompok sosial yang lain. Tinggi dan rendahnya mobilitas sosial kelompok maupun individu di dalam masyarakat tergantung dengan bagaimana kondisinya.Pada masyarakat yang memiliki kelas sosial terbuka, maka masyarakatnya memiliki tingkat mobilitas yang tinggi.Sebaliknya masyarakat yang memiliki kelas sosial yang tertutup cenderung memiliki tingkat mobilitas yang rendah.Hal itu disebabkan kelas tersebut sulit menerima kemajuan atau modernisasi sehingga kelas sosial tersebut monoton.

Mobilitas sosial yang terjadi pada suatu masyarakat menunjukkan tingginya aksesibilitas masyarakat tersebut sehingga memudahkan gerak sosial masyarakat khusunya dalam kegiatan sosial-ekonomi.Aksesibilitas merupakan penerimaan atau penolakan suatu inovasi adalah keputusan yang dibuat oleh seseorang. Jika ia menerima inovasi maka ia telah menggunakan ide baru, praktik baru atau barang baru dan menghentikan penggunaan ide-ide yang digantikan oleh inovasi itu. Keputusan inovasi adalah proses mental, sejak seseorang mengetahui adanya inovasi sampai mengambil keputusan untuk menerima atau menolaknya yang dilatari oleh keyakinan tentang keberadaan inovasi, kemudian mengukuhkannya. Bekerjanya komponen inovasi baik secara simultan maupun bervariasi mempertinggi derajat daya terima atau aksesibilitas (accessibility) masyarakat. Artinya pintu masuk untuk dapat akses pada suatu situasi atau keadaan. Dalam kaitannya dengan pengertian tersebut, aksesibilitas diartikan sebagai kemampuan menerima sesuatu (Morris, 1981). Salah satu yang diterima dari dengan adanya aksessibilitas adalah peningkatan status sosial ekonomi.

Sosial ekonomi dapat diartikan sebagai segala sesuatu yang berkaitan dengan pemenuhan kebutuhan masyarakat antara lain dalam sandang, pangan, perumahan, pendidikan, dan lain-lain. Pemenuhan yang dimaksud berkaitan dengan penghasilan/pendapatan. Pendapatan adalah sejumlah penghasilan dari seluruh anggota keluarga baik dalam bentuk uang maupun barang yang dinilai dengan sejumlah beras.

Kesejahteraan seseorang dipengaruhi oleh besarnya pendapatan keluarga.Pendapatan adalah sejumlah penghasilan dari seluruh anggota keluarga. Semakin tinggi tingkat pendapatan kader maka kader akan semakin aktif dalam kegiatan posyandu. Pendidikan seseorang merupakan faktor penting dalam memperoleh kesempatan kerja yang lebih baik bila dibandingkan dengan seseorang yang berpendidikan rendah.

Kondisi sosial ekonomi sebagai kaitan antara status sosial dan kebiasaan hidup sehari-hari yang telah membudaya bagi individu atau kelompok di mana kebiasaan hidup yang membudaya ini biasanya disebut dengan Culture Activity, kemudian ia juga menjelaskan pula bahwa dalam semua masyarakat di dunia baik yang sederhana maupun yang kompleks, pola interaksi atau pergaulan hidup antara individu menunjuk pada perbedaan kedudukan dan derajat atau status kriteria dalam membedakan status pada masyarakat yang kecil biasanya sangat sederhana, karena disamping jumlah warganya yang relatif sedikit, juga orang-orang yang dianggap tinggi statusnya tidak begitu banyak jumlah maupun ragamnya. 
Sementara W.S Winke (dalam Haryanto, 2011) menyatakan bahwa pengertian status sosial ekonomi mempunyai makna suatu keadaan yang menunjukan pada kemampuan finansial keluarga dan perlengkapan material yang dimilki, dimana keadaan ini bertaraf baik, cukup, dan kurang. Berdasarkan pendapat para ahli tersebut dapat dinyatakan bahwa kondisi sosial ekonomi adalah posisi individu dan kelompok yang berkenaan dengan ukuran rata-rata yang berlaku umum tentang pendidikan, pemilikan barang-barang, dan patisipasi dalam aktivitas kelompok dari komunitasnya, sedangkan kondisi sosial ekonomi kaitanya dengan status sosial ekonomi itu sendiri dengan kebiasaan hidup seharihari individu atau kelompok.

Perpindahan kelas dari kelas bawah ke kelas atas seyogianya dikatakan sebagai mobilitas sosial. Kelas yang dimaksud dalam penelitian ini adalah kelas sosial yang diterangkan oleh Giddens (Ritzer, 2012), yaitu pembagian kelas sosial pada masyarakat dari kelas bawah (low), menengah (middle), dan atas (upper). Kemudian pada tiap kelas terbagi lagi menjadi 3 golongan, yaitu kelas bawah (low), menengah (middle), dan atas(upper).

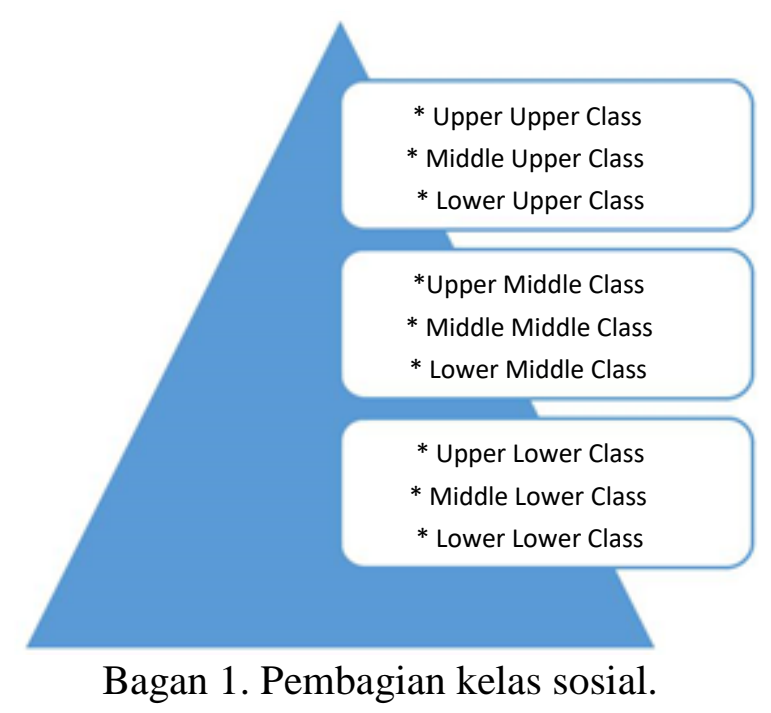

Pembagian kelas yang telah diterangkan di atas merupakan manifestasi dari mobilitas sosial yang akan dikaji dari penelitian ini. Masyarakat Nias akan senantiasa mengalami perubahan sosial yang diakibatkan oleh mobilitas sosial untuk meningkatkan kesejahteraan. Dengan demikian mobilitas sosial yang dimaksud dalam penelitian ini adalah perpindahan kelas yang terjadi pada masyarakat Nias sebagai upaya untuk mensejahterakan hidup. Dalam rangka menuju kehidupan yang sejahtera, masyarakat senantiasa memerlukan stimulus sebagai katalisator dalam mobilitas sosial. Katalisator tersebut adalah aksesiblitas yang ada pada sistem tersebut. Dengan demikian bagan alur dari mobilitas sosial menuju ke peningkatan status sosial ekonomi dapat dilihat dibawah ini.

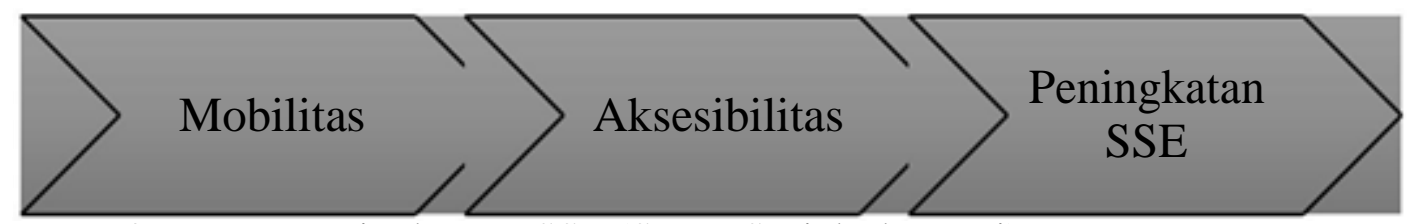

Bagan 2. Proses meningkatnya SSE (Status Sosial Ekonomi).

Mobilitas sosial adalah berpindahnya suatu kelompok dari kelas tertentu menuju ke kelas yang lain. Perpindahan yang terjadi seringkali menyakitkan baik mental maupun psikis suatu kelompok sosial, karena bermacam arah mobilitas yang berbeda-beda. Untuk itu, perlu dijembatani dengan adanya suatu aksesibilitas. Aksesibilitas merupakanPenerimaan atau penolakan suatu inovasi adalah keputusan yang dibuat oleh seseorang. Jika ia menerima inovasi maka ia telah menggunakan ide baru, praktik baru atau barang baru dan menghentikan penggunaan ide-ide 
yang digantikan oleh inovasi itu. Pada akhirnya, inovasi-inovasi yang lahir tersebut membuat mobilitas sosial menjadi lebih mudah menuju ke peningkatan sosial ekonomi.

\section{Hasil dan pembahasan}

\section{Pariwisata Di Kota Gunung Sitoli}

Kota Gunungsitoli memiliki luas wilayah 469,36 km2 atau 0,38 persen dari luas wilayah Propinsi Sumatera Utara. Jumlah penduduk Kota Gunungsitoli sendiri tahun 2013 menurut angka proyeksi BPS Kota Gunungsitoli sebanyak 129.043 jiwa.

Kepulauan Nias merupakan salah satu Daerah Tujuan Wisata (DTW) favorit bagi wisatawan baik domestik maupun luar negeri, terutama bagi penggemar wisata surfing yang sudah melegenda, atau pencinta eksotisme pantainya yang mempesona, maupun atraksi budaya dan seni tradisional yang selalu mengundang decak kagum setiap pengunjungnya.

\section{Mobilitas Sosial Penduduk}

\section{Motivasi Kerja}

Tabel 3.1 :Tanggapan Responden Terhadap Apakah Jenis Pekerjaan ini yang disukai (kuesioner no 2)

\begin{tabular}{llll}
\hline No & Kategori & Jumlah(orang) & Persen(\%) \\
1. & Tidak Setuju & 0 & 0 \\
2. & Kurang Setuju & 1 & 2,6 \\
3. & Setuju & 19 & 50,4 \\
4. & Sangat Setuju & 18 & 47,4 \\
\hline & Jumlah Total & 38 & 100 \\
\hline
\end{tabular}

Sumber: Data Kuesioner, Agustus 2016

Dari data Tabel diatas menunjukan bahwa pekerja atau karyawan yang bekerja disektor pariwisata mereka menyukai pekerjaan disektor tersebut. Fakta ini dapat dilihat dari hasil data kualitatif yang menunjukkan bahwa para pekerja menyukai bekerja disektor pariwisata karena mereka menekuni pekerjaan yang mereka yang lakukan. Para pekerja juga merasa dengan bekerja disektor pariwisata dapat meningkatkan pendapatan mereka. Apalagi para pekerja atau karyawan yang bekerja di sektor pariwisata sebelumnya tidak bekerja atau bekerja serabutan sehingga dengan bekerja disektor pariwisata tersebut dapat meningkatkan kesejahteraan.

Tabel 3.2 :Tanggapan Responden Terhadap Apakah Bekerja di sektor pariwisata ini menjamin keberlangsungan hidup mereka

\begin{tabular}{llll}
\hline No & Kategori & Jumlah(orang) & Persen $(\%)$ \\
1. & Tidak Setuju & 2 & 5,3 \\
2. & Kurang Setuju & 7 & 18,4 \\
3. & Setuju & 21 & 55,3 \\
4. & Sangat Setuju & 8 & 21,1 \\
\hline
\end{tabular}

Sumber: Data Kuesioner, Agustus 2016

Berdasarkan Tabel diatas menunjukkan bahwa Penduduk yang bekerja disektor pariwisata sebanyak lebih dari 55,3 $\%$ menyatakan setuju dengan bekerja di sektor pariwista dapat menjamin keberlangsungan hidupnya, sedangkan 18,4 $\%$ dan 5,3\% menyatakan kurang setuju dan tidak setuju. Masalah keberlangsungan hidup merupakan masalah perekonomian mereka yang berarti berhubungan dengan pendapatan. Dengan penghasilan yang didapat, karyawan dapat memenuhi kebutuhan hidup dan secara perlahan dapat meningkatkan kesejahteraan keluarganya.

Tabel 3.3 : Tanggapan Responden Terhadap Apakah Bekerja di sektor pariwisata ini dapat mengembangkan potensi 


\begin{tabular}{llll}
\hline No & Kategori & Jumlah(orang) & Persen(\%) \\
1. & Tidak Setuju & 1 & 2,6 \\
2. & Kurang Setuju & 11 & 28,9 \\
3. & Setuju & 13 & 34,2 \\
4. & Sangat Setuju & 13 & 34,2 \\
\hline & Jumlah Total & 38 & 100 \\
\hline
\end{tabular}

Sumber: Data Kuesioner, Agustus 2016

Dari tabel 3.3 diatas menunjukkan bahwa pekerjaan di tempat-tempat pariwisata menurut para responden memberikan pernyataan sangat setuju dan setuju secara bersamaan jumlahnya sebanyak 34,2\% dimana mereka mengatakan bahwa pariwisata ini memberikan kesempatan bagi mereka untuk mengembangkan potensi yang mereka miliki sedangkan 28,9\% menyatakan kurang setuju dan 2,6\% menyatakan tidak setuju. Fakta tersebut didukung oleh tempat wisata menyediakan beberapa fasilitas yang menudukung untuk membantu mereka meningkatkan kemampuan diri. Misalnya di Museum Pusaka Nias ada program pertukaran karyawan dengan museum yang ada di Bali.

Tabel 3.4 :Tanggapan Responden Terhadap Apakah Bekerja di sektor pariwisata ini Gaji yang diberikan dapat membantu kehidupan sehari-hari

\begin{tabular}{llll}
\hline No & Kategori & Jumlah(orang) & Persen(\%) \\
1. & Tidak Setuju & 3 & 7,9 \\
2. & Kurang Setuju & 4 & 10,5 \\
3. & Setuju & 23 & 60,5 \\
4. & Sangat Setuju & 8 & 21,1 \\
\hline & Jumlah Total & 38 & 100 \\
\hline
\end{tabular}

Sumber: Data Kuesioner, Agustus 2016

Dari tabel 3.4 diatas menunjukkan bahwa gaji yang diterima oleh para karyawan mencukupi untuk kebutuhan hidup sehari-hari di sekitaran lokasi industri pariwisata menurut para responden memberikan pernyataan setuju sebanyak 60,5\% dimana mereka mengatakan bahwa pariwisata ini memberikan gaji yang cukup bagus sehingga bagi mereka dapat mencukupi kebutuhanhidup merekasedangkan sangat setuju 21,1\% menyatakan kurang setuju dan 10,5\% dan sebanyak 7,9\% menyatakan tidak setuju.

Tabel 3.5 : Tanggapan Responden Terhadap Apakah di sektor pariwisata ini memberikan penghargaan kepada karyawannya

\begin{tabular}{llll}
\hline No & Kategori & Jumlah(orang) & Persen $(\%)$ \\
1. & Tidak Setuju & 3 & 7,9 \\
2. & Kurang Setuju & 3 & 7,9 \\
3. & Setuju & 21 & 55,3 \\
4. & Sangat Setuju & 11 & 28,9 \\
\hline & Jumlah Total & 38 & 100 \\
\hline
\end{tabular}

Sumber: Data Kuesioner, Agustus 2016

Dari tabel 3.5 diatas menunjukkan bahwa para karyawan yang memilih setuju dengan adanya pihak industri pariwisata memberikan penghargaan terhadap karyawannya yang berprestasi sebanyak $55,3 \%$ hal ini sebagai upaya meningkatkan semangat dalam bekerja agar lebih efektif juga dalam bekerja sehingga pekerjaan menjadi siap sesuai dengan target. Sedangkan sebanyak 28,9\% sangat setuju dan sebanyak 7,9\% masing-masing memilih tidak setuju dan kurang setuju. 


\section{Frekuensi Aktifitas}

Tabel 3.6 : Tanggapan Responden Apakah di Sektor Pariwisata ini Memberikan Upah yang Sesuai Terhadap Karyawan

\begin{tabular}{llll}
\hline No & Kategori & Jumlah(orang) & Persen(\%) \\
1. & Tidak Setuju & 4 & 10,5 \\
2. & Kurang Setuju & 11 & 28,9 \\
3. & Setuju & 15 & 39,5 \\
4. & Sangat Setuju & 8 & 21,1 \\
\hline & Jumlah Total & 38 & 100 \\
\hline
\end{tabular}

Sumber: Data Kuesioner, Agustus 2016

Pada Tabel 3.6 diatas menjelaskan bahwa para karyawan yang memilih setuju dengan adanya pemberian upah yang sesuai sebanyak 39,5\% hal ini sebagai upaya meningkatkan semangat dalam bekerja agar lebih efektif juga dalam bekerja sehingga pekerjaan menjadi siap sesuai dengan target. Sedangkan sebanyak 28,9\% kurang setuju dan sebanyak $21,1 \%$ memilih sangat setuju dan yang memilih tidak setuju setuju.

Tabel 3.7 : Tanggapan Responden Terhadap Pertanyaan Apakah Para Pekerja akan tetap giat bekerja meskipun tidak diawasi pemilik usaha (kuesioner no 5)

\begin{tabular}{llll}
\hline No & Kategori & Jumlah(orang) & Persen(\%) \\
1. & Tidak Setuju & 0 & 0 \\
2. & Kurang Setuju & 1 & 2,6 \\
3. & Setuju & 21 & 55,3 \\
4. & Sangat Setuju & 14 & 36,8 \\
\hline & Jumlah Total & 38 & 100
\end{tabular}

Sumber: Data Kuesioner, Agustus 2016

Berdasarkan Tabel 3.7diatas menyatakan bahwa para responden sebanyak 55,3\% memilih setuju jika mereka tetap bekerja dengan baik dan giat meskipun tidak ada pemilik usahanya. Hal ini mereka lakukan karena mereka tidak ingin jika kinerja mereka buruk hanya karena tidak ada yang mengawasi. Bagi masyarakat kepercayaan yang sudah di berikan kepada mereka dari para pemilik usaha harus dijaga dengan baik. sedangkan sebanyak 36,8\% sangat setuju, hal ini dikarenakan rasa kepercayaan yang tidak ingin di hianati meskipun sang pemilik tidak ada mereka harus tetap bekerja dengan baik. Tidak ada responden yang menyatakan bahwa mereka tidak setuju hanya ada 2,6\% yang menyatakan kurang setuju dengan hal ini dikarenakan dia hanya karyawan tidak tetap.

\section{Status Sosial Ekonomi}

Pada penelitian ini menggunakan dua metode yakni kuantitatif dan kualitatif sehingga menguji dua variabel untuk membuktikan bahwa apakah kedua variabel memiliki hubungan yang saling berkaitan satu dengan yang lain secara kuat. Untuk itu dalam penelitian ini variabel yang di pengaruhi adalah status sosial ekonomi dengan indikator sebagai berikut:

Tabel 3.8 : Tanggapan Responden Terhadap Pertanyaan Apakah Sektor Pariwisata ini Menjadi Satu-satunya Peluang Bagi Mereka Untuk Meningkatkan Kesejahteraan (kuesioner no 1)

\begin{tabular}{llll}
\hline No & Kategori & Jumlah(orang)
\end{tabular}




\begin{tabular}{llll} 
1. & Tidak Setuju & 5 & 13,2 \\
2. & Kurang Setuju & 7 & 18,4 \\
3. & Setuju & 19 & 50,0 \\
4. & Sangat Setuju & 7 & 18,4 \\
\hline & Jumlah Total & 38 & 100 \\
\hline
\end{tabular}

Sumber: Data Kuesioner, Agustus 2016

Berdasarkan Tabel diatas, menyatakan bahwa para responden sebanyak 50,0\% memilih setuju jika industri pariwisata ini menjadi satu-satunya peluang bagi mereka untuk meningkatkan kesejahteraan mereka yang sudah sejak lama tertinggal tidak ada kemajuan sama sekali, oleh karena itu mereka sangat mengapresiasikan adanya industri pariwisata ini. sedangkan sebanyak $18,4 \%$ sangat setuju, hal ini dikarenakan menurut mereka bahwa mereka mengalami perubahan yang sangat signifikan dalam hal ekonomi sejak hadirnya pariwisata ini. Sedangkan sebanyak $13,2 \%$ responden yang menyatakan bahwa mereka tidak setuju dengan kehadiran pariwisata ini, hal ini dikarenakan bahwa mereka memiliki alasan bahwa masyarakat tidak lagi menjadi masyarakat yang akrab tetapi cenderung konsumtif, membeli sesuatu secara berlebihan sehingga tidak meningkatkan kesejahteraan mereka.

Tabel 3.9 : Tanggapan Responden Terhadap Pertanyaan Apakah Sektor Pariwisata ini Memberikan Peluang Bagi Mereka Untuk Meningkatkan pendapatan dan memperluas usaha

\begin{tabular}{llll}
\hline No & Kategori & Jumlah(orang) & Persen $(\%)$ \\
1. & Tidak Setuju & 1 & 2,6 \\
2. & Kurang Setuju & 12 & 31,6 \\
3. & Setuju & 19 & 50,0 \\
4. & Sangat Setuju & 6 & 15,8 \\
\hline & Jumlah Total & 38 & 100 \\
\hline
\end{tabular}

Sumber: Data Kuesioner, Agustus 2016

Berdasarkan Tabel 3.9 diatas, menyatakan bahwa para responden sebanyak 50,0\% memilih setuju jika industri pariwisata ini menjadi peluang bagi mereka untuk meningkatkan pendapatan serta memperluas akses jaringan mereka yang sudah sejak lama tertinggal tidak ada kemajuan sama sekali, oleh karena itu mereka sangat mengapresiasikan adanya industri pariwisata ini. sedangkan sebanyak $15,4 \%$ sangat setuju, hal ini dikarenakan menurut mereka, dikawasan sekitar pariwisata ini mengalami perubahan yang sangat signifikan dalam hal ekonomi serta pembangunan infrastruktur sejak hadirnya pariwisata ini. Sedangkan sebanyak 31,6\% responden yang menyatakan bahwa mereka tidak setuju dengan kehadiran pariwisata ini, hal ini dikarenakan bahwa masyarakat tidak lagi menjadi masyarakat yang akrab tetapi cenderung konsumtif, membeli sesuatu secara berlebihan sehingga tidak meningkatkan kesejahteraan mereka.

Tabel 3.10 : Tanggapan Responden Terhadap Pertanyaan Apakah Sektor Pariwisata ini Memberikan Pengaruh bagi Mereka Untuk meningkatkan Status Sosial dan Mobilitas Sosial Mereka

\begin{tabular}{llll}
\hline No & Kategori & Jumlah(orang) & Persen(\%) \\
1. & Tidak Setuju & 8 & 21,1 \\
2. & Kurang Setuju & 8 & 21,1 \\
3. & Setuju & 14 & 36,8 \\
4. & Sangat Setuju & 8 & 21,1 \\
\hline & Jumlah Total & 38 & 100 \\
\hline
\end{tabular}

Sumber: Data Kuesioner, Agustus 2016 
Berdasarkan Tabel 3.10 diatas menyatakan bahwa para responden sebanyak 36,8\% memilih setuju jika industri pariwisata ini menjadi pengaruh bagi mereka untuk meningkatkan status sosial dan mobilitas sosial mereka serta memperluas akses jaringan mereka untuk memiliki usaha lebih dari satu dikawasan pariwisata Nias ini, oleh karena itu mereka sangat mengapresiasikan adanya industri pariwisata ini. sedangkan sebanyak $21,1 \%$ sangat setuju, hal ini dikarenakan menurut mereka, dikawasan sekitar pariwisata ini mengalami perubahan yang sangat signifikan dalam hal kehidupan sosial masyarakat sejak adanya industri pariwisata ini. Sedangkan sebanyak $21,1 \%$ responden yang menyatakan bahwa mereka tidak setuju dan kurang setuju dengan kehadiran pariwisata ini, hal ini dikarenakan bahwa masyarakat tidak lagi menjadi masyarakat yang akrab tetapi cenderung individualis yang tidak peduli dengan masyarakat sekitar.

\section{Kesimpulan dan saran}

Pembangunan sektor industri pariwisata yang terus berkembang telah mampu memberikan peluang kerja dan mata pencaharian baru bagi masyarakat yang sebelumnya tidak mengetahui tentang dunia industri pariwisata.Dengan kata lain, dengan adanya pembangunan ini mampu memberikan pengetahuan baru tentang dunia kerja yang tidak hanya terfokus pada pertanian saja dan juga membantu masyarakat agar ekonomi lebih baik lagi, mampu menambah penghasilan untuk kebutuhan sehari-hari meskipun masyarakat saat ini masih sebatas pekerja harian atau karyawan tidak tetap.

Berdasarkan tabel analisis diatas juga menjelaskan bahwa antara kedua variabel memiliki nilai yang signifikan.Dalam hal ini industri pariwisata yang terus meningkat memberikan pengaruh yang sangat positif bagi kesejahteraan di kalangan masyarakat Gunung Sitoli. Pembangunan industri Pariwisata ini juga berhasil merubah kepercayaan masyarakat sekitar terhadap pantai. Jika dahulu sebelum masuknya industri pariwisata, mereka menganggap pantai hanya sebagai tempat mencari ikan sebagai nelayan saja tetapi bisa dijadikan hal lain yang lebih menguntungkan.

Berdasarkan hasil penelitian dan pengamatan selama penelitian, peneliti melihat ada beberapa hal yang perlu diperhatikan. Saran ini diharapkan dapat menjadi masukan postif demi kebaikan bersama. Adapun saran tersebut adalah sebagai berikut :

1. Perlunya penyadaran bagi masyarakat khususnya masyarakat yang berada di kawasan industri pariwisata agar lebih memperhatikan kebersihan lokasiagar para wisatawan semakin banyak yang nyaman dan suka sehingga akan kembali berkunjung.

2. Para pemilik industri pariwisata perlu ditingkatkannya sarana dan prasarana khususnya untuk para pekerja dan wisatawan agar semakin menarik untuk di kunjungi.

3. Lembaga pemerintah daerah mampu membantu menjadi jembatan masyarakat atau wisatawan dengan pihak pemilik industri pariwisata agar dapat mempromosikan kawasan pariwisata lebih luas lagi ke masyarakat ayng di luar daerah, karena keuntungannya bisa di peroleh juga oleh pemerintah daerah nantinya.

\section{References}

[1] Badan Pusat Statistik Nias. 2013. Nias Dalam Angka 2013, Gunung Sitoli: BPS.

[2] Badan Perencanaan Pembangunan Daerah Kota Gunungsitoli.2014._Data dan Informasi Statistik Daerah Kota Gunungsitoli Tahun 2014, 2014, hal 1.

[3] Famytyas dan Kusumastuti. 2014. “Peranan Sektor Pariwisata Dalam Perekonomian Indonesia : Analisis Input-Output”. Jurnal Ekonomi Pembangunan Tri Sakti, Vol.1, No.2, Hal. 93-108.

[4] Haryanto, D. 2011. Pengantar Sosiologi Dasar. Jakarta: PT Prestasi Pustakaraya.

[5] Horton. Paul B and Chester L. Hunt. 1992. Sosiologi Jilid 2. Jakarta: Erlangga.

[6] Luthfi, Renaldy Rahkman. 2013. - Peran Pariwisata Terhadap Kesejahteraan Masyarakat Di Sektor Lapangan Pekerjaan dan Perekonomian Tahun 2009-2013\|. Jurnal Ilmiah, Malang : Universitas Brawijaya.

[7] Sarwono, SW. 2005. Psikologi Sosial Psikologi Kelompok dan Psikologi Terapan. Jakarta: Balai Pustaka.

[8] Soekanto, S. 2012. Sosiologi Suatu Pengantar. Jakarta: PT RajaGrafindo Persada.

[9] Sismudjito. 2004. Pengembangan Sektor Pariwisata Dalam Pertumbuhan Ekonomi Daerah. 
[10] Jurnal Ekonomi Volume 8, Nomor 2. Medan: Fakultas Ekonomi USU.

[11] Sunarto, Kamanto. 2004. Pengantar Sosiologi. Jakarta: Fakultas Ekonomi UI 